\title{
Statement to Kösler et al. 2019 and 2020 regarding the evaluation of the ecotoxicity of nitrification inhibitors using terrestrial and aquatic test organisms
}

Gregor Pasda* (D) and Markus Schmid

\section{Abstract}

In this paper, the correct composition of Vizura is given and a note that the founded results concerning ecotoxicity of Vizura are of no relevance for the recommended application rates for Vizura.

Keywords: Vizura, DMPP, Nitrification inhibitor, Ecotoxicity

\section{Statement}

1. In both papers of Kösler et al. $[1,2]$ the information on the product composition of Vizura is incorrect. Vizura does not contain 1,2,4-triazol [1] (corrected in [2]) nor $1 \mathrm{H}$-pyrazole [2]. Vizura is a liquid formulation of $14 \% \mathrm{w} / \mathrm{w}$ 3,4-dimethylpyrazole phosphate in phosphoric acid and water.

2. Kösler et al. [1] are not using the recommended use rate of Vizura. The minimum test concentrations used in the different ecotoxicity tests in Kösler et al. [1] are higher than the DMPP concentration applied in agricultural practice with Vizura. Therefore, the results of Kösler et al. [1] concerning ecotoxicity of Vizura are of no relevance for the recommended application rates for Vizura used according to good agricultural practice.

\section{Abbreviation \\ DMPP: 3,4-Dimethylpyrazole phosphate.}

\section{Acknowledgements}

Not applicable.

Authors' contributions

GP initiated the text. Both authors made substantial and equal contributions to the initial draft. Both authors read and approved the final manuscript.

\section{Funding}

Not applicable.

\section{Availability of data and materials \\ Not applicable.}

Ethics approval and consent to participate Not applicable.

\section{Consent for publication}

Not applicable.

\section{Competing interests}

The authors declare that they have no competing interests.

Received: 6 July 2020 Accepted: 12 August 2020

Published online: 28 August 2020

*Correspondence: gregor.pasda@basf.com

BASF SE, Speyerer Straße 2, 67117 Limburgerhof, Germany adaptation, distribution and reproduction in any medium or format, as long as you give appropriate credit to the original author(s) and the source, provide a link to the Creative Commons licence, and indicate if changes were made. The images or other third party material in this article are included in the article's Creative Commons licence, unless indicated otherwise in a credit line to the material. If material is not included in the article's Creative Commons licence and your intended use is not permitted by statutory regulation or exceeds the permitted use, you will need to obtain permission directly from the copyright holder. To view a copy of this licence, visit http://creativecommons.org/licenses/by/4.0\%. 


\section{References}

1. Kösler JE, Calvo OC, Franzaring J, Fangmeier A (2019) Evaluating the ecotoxicity of nitrification inhibitors using terrestrial and aquatic test organisms. Environ Sci Eur 31:91

2. Kösler JE, Calvo OC, Franzaring J, Fangmeier A (2020) Correction to: Evaluating the ecotoxicity of nitrification inhibitors using terrestrial and aquatic test organisms. Environ Sci Eur 32:56

\section{Publisher's Note}

Springer Nature remains neutral with regard to jurisdictional claims in published maps and institutional affiliations.
Submit your manuscript to a SpringerOpen ${ }^{\circ}$ journal and benefit from:

- Convenient online submission

- Rigorous peer review

- Open access: articles freely available online

- High visibility within the field

- Retaining the copyright to your article

Submit your next manuscript at $\boldsymbol{\nabla}$ springeropen.com 